\title{
Albert Einstein Memorial Lectures
}


This page intentionally left blank 


\title{
Albert Einstein Memorial Lectures
}

\author{
Editors \\ Jacob D. Bekenstein \\ Raphael Mechoulam
}




\title{
Published by
}

The Israel Academy of Sciences and Humanities

Albert Einstein Square

P.O. Box 4040

Jerusalem 91040

Israel

and

World Scientific Publishing Co. Pte. Ltd.

5 Toh Tuck Link, Singapore 596224

USA office: 27 Warren Street, Suite 401-402, Hackensack, NJ 07601

UK office: 57 Shelton Street, Covent Garden, London WC2H 9HE

"The Structure of Quarks and Leptons" by Haim Harari is reprinted from the Scientific American, April 1983, pp. 48-60.

"Beautiful Theories" by Steven Weinberg is reprinted from Dreams of a Final Theory by Steven Weinberg, copyright (C1992 by Steven Weinberg. Used by permission of Random House, Inc., throughout the world excluding the UK, and of Vintage, an imprint of The Random House Group, Ltd., in the UK.

\author{
ALBERT EINSTEIN MEMORIAL LECTURES \\ Copyright $(2012$ by The Israel Academy of Sciences and Humanities \\ All rights reserved.
}

ISBN-13 978-981-4329-42-2

ISBN-10 981-4329-42-8

ISBN-13 978-981-4329-43-9 (pbk)

ISBN-10 981-4329-43-6 (pbk)

Printed in Singapore. 


\section{Preface}

Albert Einstein was a leader in establishing the foundations of scientific research in Israel. In the 1920s, when the Hebrew University of Jerusalem the first university in what was then British-Mandate Palestine — was founded, Einstein was elected Head of the Academic Council of the Board of Governors. Both the administration and the staff assumed that he would be a distinguished figurehead, but, to everyone's surprise, he became very involved in the new university's activity. While its American financial backers presumably had envisioned something on the model of an Americantype college, he aspired for the Hebrew University to follow in the tradition of the great European research universities. Einstein's insistence led to the formation of an international academic committee, which duly visited Jerusalem and strongly supported his understanding of how the university should develop. This conception became the intellectual basis not only of the Hebrew University, but of all the universities established thereafter in Israel. The Technion in Haifa, founded before the Hebrew University as a technical college, was also gradually transformed into a research institution.

Einstein's relations with the Hebrew University were turbulent at times, but he maintained them until the end of his life, and he bequeathed his archives to the university. Several of his students and colleagues joined the faculties of Israeli academic institutions.

Einstein was not only one of the outstanding scientists of the twentieth century; he was also a symbol of intellectual independence and leadership. Unlike most German academics, he refused to support the German entry into World War I. He was one of the first academics to recognize the danger of Nazism, and most major scientists followed his call. Notwithstanding his deeply rooted pacifism, he feared that the West would be preempted by Nazi Germany in developing atomic energy for military purposes, leading him to initiate its development in the United States by penning his famous letter to President Roosevelt.

David Ben-Gurion invited Einstein to become the first President of the State of Israel - an offer he turned down. He valued his independence and could not envision himself becoming absorbed in official receptions and duties of state. 
For us, as scientists, he represents the ultimate personal ideal - a researcher who opened new vistas in science and an intellectual who led by personal example, without the need of official titles or positions.

With the annual Albert Einstein Memorial Lectures, the Israel Academy of Sciences and Humanities conveys its aspiration to sustain the legacy of this intellectual giant.

The editors thank, first and foremost, the contributors, for allowing us to publish their lectures. We are also grateful to Professor Yohanan Friedmann and the Publications Committee of the Israel Academy of Sciences and Humanities, which he headed until recently, for their guidance of this project; to the Director of the Academy's Publications Department, Ms. Tali Amir; and especially to Ms. Deborah Greniman, its Senior Editor of English-language Publications, for her inestimable help. Ms. Esther Rosenfeld gave the volume an expert round of proofreading. Our thanks, finally, to World Scientific Publishing for proposing the publication of this volume and for their care and cooperation in producing it.

Jacob Bekenstein and Raphael Mechoulam Jerusalem, July 2011 


\section{List of Contributors}

Timothy Gowers wrote his Ph.D. on the geometry of Banach spaces and went on to solve several old problems in that area, some due to Banach himself. In 1998 he received a Fields Medal, partly for this work and partly for a highly influential new proof of Szemerédi's theorem. He is currently a Royal Society Research Professor at Cambridge University.

Haim Harari is Annenberg Professor of High-Energy Physics at the Weizmann Institute and Chairman of the Davidson Institute of Science Education. He is a member of the Israel Academy of Sciences and the American Academy of Arts and Sciences, and recipient of, among others, the Rothschild Prize in Physics (Yad Hanadiv, 1976), the Israel Prize, the EMET Prize in Education (A.M.N. Foundation for Science, Art and Culture, sponsored by the Prime Minister of Israel, 2004), and the Harnack Medal (Max Planck Society, 2001). He was President of the Weizmann Institute (19882001), Chairman of the Planning and Budgeting Committee of Israel's Council for Higher Education (1979-1985), and co-founder of Perach, a national tutoring program for underprivileged children in Israel.

Roger Kornberg is Winzer Professor of Medicine in the Department of Structural Biology at Stanford University. As a postdoctoral fellow and member of the scientific staff at the Laboratory of Molecular Biology in Cambridge, England (1972-1975), he discovered the nucleosome, the basic unit of DNA coiling in chromosomes. He is the recipient of the Welch Award in chemistry (2001), the Leopold Mayer Prize in biomedical sciences (French Academy of Sciences, 2002) and the Nobel Prize in Chemistry (2006).

Yuan T. Lee, former President of the Academia Sinica (1994-2006), was co-recipient of the Nobel Prize in Chemistry (1986) for his contributions concerning the dynamics of chemical elementary processes, particularly his development of the method of crossed molecular beams for the study of important reactions for relatively large molecules. He is a member of the (U.S.) National Academy of Sciences and of Academia Sinica, and the recipient of, among others, the National Medal of Science (awarded by the President of the United States, 1986), the Peter Debye Award (American Chemical Society, 1986) and the Faraday Medal (Royal Society of Chemistry, London, 1992). 
Jean-Marie Lehn is Director of the Institut de Science et d'Ingénierie Supramoléculaires (ISIS) in Strasbourg and Professor of Chemistry at the Collège de France. He was awarded the Nobel Prize in Chemistry (1987), together with Charles J. Pedersen and Donald J. Cram, for their development and use of molecules with structure-specific interactions of high selectivity.

Carlo Rubbia is best known for his discovery of $\mathrm{W}$ and $\mathrm{Z}$ particles, for which he was awarded the Nobel Prize in Physics (1984), and for his proposal for a safe nuclear reactor in the form of a coupled acceleratorreactor using thorium as fuel. He has been instrumental in the development and operation of the European Laboratory for Particle Physics (CERN) in Geneva and served as the Laboratory's Director-General for five years (1989-1993).

Shlomo Sternberg is George Putnam Professor of Pure and Applied Mathematics at Harvard University. Best known for his work on symplectic geometry, he is a Fellow of the American Academy of Arts and Sciences, the (U.S.) National Academy of Sciences and the Royal Academy of Spain, and he has been a Visiting Fellow of the Mortimer and Raymond Sackler Institute of Advanced Studies, Tel Aviv University.

John E. Wansbrough (1928-2002) was Professor of Semitic Studies and Pro-Director at the School of Oriental and African Studies of London University. He revolutionized the scholarly study of Islamic origins with his groundbreaking, controversial works Quranic Studies (1977) and The Sectarian Milieu (1978), in which he argued that the Koran, like the Jewish and the Christian Bible, was the product of a long period of gestation, resulting in a distinctive version of the biblical tradition of monotheism, on the same historical and theological footing as its predecessors.

Steven Weinberg is Professor of Physics and Astronomy at the University of Texas, where he holds the Jack S. Josey-Welch Foundation Regents Chair in Science, and was formerly Higgins Professor of Physics at Harvard (1973-1982). His honors include the Nobel Prize in Physics (1979) and the National Medal of Science (awarded by the President of the United States, 1991), election to numerous academies and sixteen honorary doctoral degrees. 


\section{Contents}

Preface $\quad$ V

List of Contributors $\quad$ vii

What Can Pure Mathematics Offer to Society? 1

W. Timothy Gowers

General Covariance and the Passive Equations of Physics 21

Shlomo Sternberg

The Structure of Quarks and Leptons

Haim Harari

Beautiful Theories

Steven Weinberg

Harmless Energy from Nuclei

Carlo Rubbia

Supramolecular Chemistry: From Molecular Information toward Self-Organization and Complex Matter

Jean-Marie Lehn

Chromatin and Transcription

Roger Kornberg

Energy, Environment, and the Responsibility of Scientists Yuan T. Lee

Res Ipsa Loquitur: History and Mimesis

John E. Wansbrough 